\title{
Secondary Cities in West Africa: Urbanity, Power, and Aspirations
}

\section{Carole Ammann ${ }^{1}$ D $\cdot$ Aïdas Sanogo ${ }^{2} \cdot$ Barbara Heer $^{3}$}

Accepted: 18 October 2021 / Published online: 31 October 2021

(C) The Author(s) 2021

\begin{abstract}
This article claims space for secondary cities in urban studies. It criticizes that scientists tend to study urban life in metropolises and, hence, do not represent urban life in its full diversity. In reality, the majority of the worlds' urban dwellers live in secondary cities; therefore, research on urbanity should reflect this fact. The article argues against simple approaches to secondary cities, such as defining them based on a single quantitative variable like population size. It rather proposes that anthropological research has a unique potential to reveal the urban dwellers' relational and situational perceptions of, and perspectives towards, secondary cities. The paper puts this approach into practice by examining two West African secondary cities: Kankan in Guinea and Bouaké in Côte d'Ivoire.
\end{abstract}

Keywords Secondary cities · Comparison · Urban life · Urban dwellers · Côte d'Ivoire · Guinea

Carole Ammann

c.ammann@uva.nl

Aïdas Sanogo

aidas.sanogo@gmail.com

Barbara Heer

barbara.heer@gmail.com

1 Amsterdam Institute for Social Science Research (AISSR), University of Amsterdam, Amsterdam, the Netherlands

2 University Centre of Manga, Manga, Burkina Faso

3 Institute of Social Anthropology, University of Basel, Basel, Switzerland 


\section{Introduction}

Ms. Coulibaly ${ }^{1}$ is a middle-aged businesswoman who spends her time between her two homes, one being her trading base in Abidjan, Côte d'Ivoire's economic capital with roughly 4.4 million inhabitants ${ }^{2}$, and the other being in Bouaké, where she grew up, the country's second most populated city with an estimated population of 610,000. During an interview in her office, Ms. Coulibaly complained how noisy and stressful Abidjan was in comparison with Bouaké. Her business partner complained that major companies and jobs were based in Abidjan, while Bouaké had very few. According to him, the government should urgently encourage businesses to move to Bouaké to stimulate economic development. Like in Ghana, where the two biggest cities, Accra and Kumasi, are both economic centers, in Côte d'Ivoire, economic power should be equally distributed across the major cities, he said. Ms. Coulibaly is convinced that Bouaké will eventually take over some of Abidjan's economic and political power, because she observed that Abidjan was getting increasingly saturated over the years. She evaluated this trend as negative, because economic activities and political influence also brought along stress and noise. For her, being able to withdraw from the bustling metropolis to the quieter secondary city was agreeable: "Here, I can charge my batteries, it's quiet, I can rest. Let's keep the stress in Abidjan!" (14.11.2015, interview).

This ethnographic vignette exemplifies that from the dwellers' and researchers' point of view, there are many different types of cities and many forms of city life, within a country, within a region, and even more so across the globe. Cities like Bouaké in Côte d'Ivoire and Kankan in Guinea, both of which this article focuses on, constitute what we call secondary cities. As Ammann and Sanogo (2017: 6) have argued, such secondary cities act as "nodal points between the rural and the urban". By secondary cities (or ville moyenne as our interlocutors would say), we mean cities that urban dwellers consider to be less important compared to large metropolises, but more significant than small towns, that constitute part of their own frame of reference and their own urban experiences. We use the term "secondary city" instead of other notions such as "second city," defined by Umbach (2005) as the second most important urban center within a country, or "second-tier city" to avoid a ranking in a nationally defined urban hierarchy. We also refrain from using "intermediate city" as this notion is related to the development discourse (e.g., Roberts, 2014; Satterthwaite \& Tacoli, 2003).

The vignette also shows that comparison, thus a relational understanding of cities, as an emic and academic practice, should be key to approaching secondary cities, and, we believe, should also be key for any engagements with cities. ${ }^{3}$ For Ms. Coulibaly, Bouaké is a quiet refuge in comparison with Abidjan's bustling life, yet one with urban amenities in comparison with the rural areas. The frame of comparison, i.e., what kind of cities urbanites compare "their" secondary city to, is not so much defined by national borders or population. It rather reflects the real or imaginary

\footnotetext{
1 All names are changed to ensure the interlocutors' anonymity.

2 All the figures and ranks concerning Côte d'Ivoire in this paper are drawn from the 2014 Ivorian national census.

${ }^{3}$ For more information regarding our approach to a comparative ethnography of cities, see Heer (2019).
} 
connections the urban dwellers' life worlds have to elsewhere, to rural areas, and to other cities in the region, the continent, and the globe. Robinson (2013: 2, italics added by the authors) contends that this "elsewhere is crucial to how cities are experienced and produced." The way urbanites perceive their own cities is shaped by their comparisons and we contend that these comparative experiences should also be put at the forefront of any anthropological analysis of (secondary) cities.

Much of the research on urbanity has focused on large cities; secondary cities like Kankan and Bouaké, in contrast, have received much less attention (Bell \& Jayne, 2006, 2009; Hilgers, 2009, 2012; Krause, 2013). Furthermore, academics often characterize secondary cities by what they lack compared to metropolises (Roberts \& Hohmann, 2014). However, big (African) cities "are not the 'only game in town'" (Malaquais \& Diallo, 2013: 59) and as the World City Report by the UN Habitat (2016) demonstrates, the number of secondary cities, as well as the number of people living therein, has increased. In this article, we focus on such secondary cities, which, we believe, should not be seen as deficient copies of metropolises but as fully urban in their own ways. We claim that the forms of urban life that exist in less spectacular places, or "boring cities" as Krause (2013) puts it, should be explicitly considered if we want to understand the diversity of cities. By neglecting everyday urban life in secondary cities and small towns, understandings of urbanity remain partial and incomplete.

By urbanity, we mean the urbanites' different forms of living together in cities, namely the ways they relate to, connect with, and deal with others (Heer, 2019). Urbanity as a social practice is characterized by a fundamental tension, emerging from the co-presence of encounter and distanciation (Förster, 2013), of creating differences and similarities. While previous formulations attempted to define urbanity in universal terms based on Western experience, the comparison we propose here approaches urbanity based on the diversity of forms of urban life.

Research on secondary cities in Africa has been limited till now. In the late 1970s, development officers researched secondary cities (Bertrand, 1997) due to the perceived need to fight against rural-urban migration (Werthmann, 2004: 7). Since the 1990s, there has been a renewed scientific interest in African secondary cities and small towns (Baker, 1990, 1997; Bertrand, 1997; Bertrand \& Dubresson, 1997). With some notable exceptions (De Boeck et al., 2009; Hilgers, 2009, 2012; Koechlin \& Förster, 2018), recent studies on the African continent mostly analyze secondary cities in South Africa (John, 2012; Marais et al., 2016; Marais \& Cloete, 2017; Roberts \& Hohmann, 2014). Conceptually, secondary cities in Africa have typically been approached through metaphors: for example, by labeling them as "shadow cities" (De Boeck et al., 2009) or describing those cities "with little or nothing to offer in the global marketplace" as "disappearing into ruin and decay" (Murray \& Myers, 2007: 4). Lately, we have seen a growing interest from international donors that invest in the infrastructure of secondary cities on the African continent. ${ }^{4}$

\footnotetext{
${ }^{4}$ For example by the Work Bank in Ghana (https://projects.worldbank.org/en/projects-operations/proje ct-detail/P164451). While Guinea in general and Kankan in particular are completely absent of the socalled Africa Rising narrative in relation to cities (see, e.g., Côté-Roy \& Moser, 2019), Bouaké's market has recently been been rebuilt with the aid of the AFD. This happened after Sanogo had conducted her long-term research in the city and is therefore not part of the empirical data drawn on to write this paper.
} 
Like for megacities (Sorensen \& Labbé 2020), researchers typically link secondary cities to the criteria of population size (Roberts \& Hohmann, 2014; van der Merwe, 1992), connected with a ranking in terms of function within the subnational and regional context (Roberts, 2014). However, they have little consent on where to draw lines (Schmidt-Lauber, 2010). While we agree that size plays a role, quantitative criteria based on absolute numbers say very little about the political, social, cultural, and economic peculiarities and significance of a city. In this diverse and relational world of cities, a specific secondary city can look very different from another secondary city. We therefore question conceptualizations of secondary cities that focus solely on population size and ranking in the national and regional urban hierarchy.

It makes sense to define secondary cities as the urban middle ground between metropolises and small towns in relational and contextual terms (see also Roberts, 2014). Consequently, the boundaries between secondary cities and metropolises on the one end, and small towns on the other, are fluid and blurred. For the necessary relational and contextual perspectives to count, it is relevant to turn to the emic view of urban dwellers, who continuously create, impact, and transform cities as well as their perceptions. Everyday experiences and perceptions of a city differ greatly among urbanites. They may differ with dwellers' age, gender, race, cultural, educational, and economic backgrounds, as well as their place of residence (Edensor \& Jayne, 2012). Thus, we must ask, as Gough (2012: 875) reminds us: "Whose city are we investigating?"

Similar to the literature on subaltern urbanization (Mukhopadhyay et al., 2017, 2020), we aim to contribute to postcolonial urban studies by highlighting the diversities of forms and processes of ordinary urban places "outside the metropolitan shadow" (Mukhopadhyay et al., 2020: 582). We also emphasize the agency and perspective of local actors' own perceptions of their cities. Contrary to the work on subaltern urbanization, however, we do not claim that secondary cities are independent of "large, traditionally important settlements or planned cities" (Mukhopadhyay et al., 2017: 28). While that set of research looks at agglomerations, defined as clusters between 10,000 and 100,000 inhabitants (Mukhopadhyay et al., 2020: 584), we reject the use of concrete numbers for defining purposes of secondary cities.

We aim to contribute to the knowledge production on (African) secondary cities from an anthropological, actor-centered perspective which considers the residents' own perceptions of their cities. Our arguments are articulated around the examples of two West African secondary cities from neighboring countries, Bouaké and Kankan. They share some similarities and differ regarding other aspects, but both cities can be seen as typical for (at least some) secondary cities, insofar as they are not well known beyond their region. Yet, cities as such can be found all over the world, and hence constitute normality. Kankan was founded in the eighteenth century and is Guinea's second largest city in terms of inhabitants, with approximately 220,000 people (République de Guinée, 2014). The city is located $650 \mathrm{~km}$ northeast of the capital Conakry. Emerging about a century later than Kankan, Bouaké was founded in the late nineteenth century by the French military in present-day Côte d'Ivoire. Located $350 \mathrm{~km}$ from the economic capital Abidjan, Bouaké represents a 
key linking point in the trade of goods between the Southern and Northern parts of Côte d'Ivoire, as well as its neighboring countries.

Ammann conducted 12 months of fieldwork in Kankan between 2011 and 2019, Sanogo conducted fieldwork in Bouaké for a 12-month period between 2014 and 2019, and together with Heer, we wrote this article. The qualitative data presented here were collected through a variety of anthropological methods. First, we mapped the social actors and their physical and social environment, before looking at how these actors relate to each other. We also paid close attention to the city's infrastructure and the dwellers' agency therein. Then, we participated in and observed the research participants' everyday lives. Additionally, we followed their interactions in different urban spaces. Finally, we conducted individual interviews, group discussions, and had numerous informal conversations (see Ammann, 2020, and Sanogo, 2019, for a detailed methodology).

Hilgers $(2009,2012)$ has identified three themes from his analysis of Koudougou in Burkina Faso as being typical for secondary cities namely urbanity, meaning that the city's inhabitants consider themselves as urbanites, authochtony that becomes more politicized with increased decentralization, and finally, a (secondary) city's reputation. Emerging from our comparative analysis of Bouaké and Kankan, we also distinguish three topics partly similar to Hilgers', with a slightly different approach to be characteristics of secondary cities: Specifically, we look at the impact of their past histories, the importance of the city's standing and position in relation to the capital city and within national politics, and the close link between a secondary city's aspiration to its physical infrastructure. While a city's history is always of huge revelance, we contend that its past and current (dis)connections to the centers of power are of particular importance for secondary cities, as those power struggles at the national level impact a secondary city's infrastructure. We also highlight how dwellers often link their personal aspirations to the secondary city they live in. Further research on (African) secondary cities is needed to confirm whether the topics we have identified are also of concern to other secondary cities.

\section{Historical Trajectories of Secondary Cities}

\section{Kankan, the Nabaya City}

Kankan was founded in the late eighteenth century by Alpha Kabiné Kaba. By the early nineteenth century, Kankan had become a major center of trade and Islamic erudition (Goerg, 1986). Alpha Kabiné is said to have introduced a political system of city growth through the marriage of foreign men to local women called Nabaya, thanks to which merchants and migrants were integrated into Kankan's households (Osborn, 2011). Today, many of Kankan's inhabitants and politicians still affectionately call their city Nabaya, which means "welcome" in the Maninka language and is written on the four arches that signal the city's entrance. Nabaya, Kankan as a ville des venants (a city for those who come), refers to the city's openness vis-àvis foreigners. During a "Forum for the Development of Kankan's Prefecture" in 2011, the city's vice mayor stated: "Nabaya is not a simple city, but a symbol of 
democracy, of open arms, tolerance, national unity, and solidarity." (13.11.2011, recording/interview).

Interestingly, though the paradigm of Nabaya was historically used to attract foreigners, Kankan's population today is rather homogenous: the majority belongs to the Manding socio-cultural group while the Fulani socio-cultural group constitutes the largest minority. Kankan's population, predominantly Muslim, is proud of the peaceful conviviality of religions, which they consider to be an intrinsic part of Nabaya. Kankan does not show huge economic disparities, neither is there spatial segregation. The city cannot be characterized as cosmopolitan; indeed, there are few international non-governmental organizations (NGOs) in Kankan and not many "expats" as compared to the capital city Conakry.

A further way how Kankan's younger inhabitants perceive their city is related to local understandings of "tradition". Often, they refer to their city as a "traditional" city (ville traditionnelle), where religious and customary norms are important and the political and social influence of elders is considerable. Kankan's young inhabitants usually differentiate between the "modern" city, by which they mean cities like Abidjan, Conakry, and Bamako, and the "traditional" village, by which they mean rural areas. In their emic perception, Kankan stands as somewhere between the "modern" city and the "traditional" village: Kankan is a city, yet also very much attached to what they see as "traditional" values. Thus, young urban dwellers see their city in relation to elsewhere, namely the big "modern" cities and the "traditional" rural area that, in their view, begins right after Kankan's outskirts.

This also has political dimensions: in the secondary city of Kankan, the central government's influence is less pronounced than in Conakry. This limited impact of state institutions gives its population more room to maneuver and improvise (Koechlin \& Förster, 2018); thus, it breeds different forms of governance than in Guinea's capital. In Kankan, the "traditional" authorities, namely the Sotikemo ${ }^{6}$ and the council of elders, have considerable influence on the local state institutions-like in other Guinean secondary cities (Rey, 2016).

The notion of Kankan as a ville traditionnelle is fostered by many means, not least through the private radio stations. Ms. Boumbaly, a young female radio journalist, recounted that the listeners complain if her radio openly criticizes the local authorities. For instance, a critique of their corrupt practices is seen as problematic: "Here in Kankan, there are things our auditors remind us not to say on the radio, exactly because Kankan is considered as a ville traditionnelle" (06.03.2012, interview). Similarly, a young male journalist advised other young men in his radio program not to wear their trousers too low on their hips and young women not to wear tight trousers and skirts that show their knees, as he considered such dress practices as inappropriate for the ville traditionnelle.

This attitude demonstrates how ways of dressing, gesturing, and moving through the city, as well as norms regarding such practices, can differ between metropolises

\footnotetext{
5 We understand modernity as an ambivalent phenomenon that "seems to refer to a basic sense of living in a new time" (Geschiere et al., 2008: 2).

6 Kankan's population refers to the Soutikemo as the city's "traditional" chief.
} 
and secondary cities and can, hence, give them distinct characteristics experienced by urban dwellers in everyday life. While in the metropolises, one can observe a huge variety of styles that are influenced by the global, national, and local levels, in a ville traditionnelle like Kankan, the codes of conduct can be stricter. Such practices, however, also differ within and across social spaces in the very same city.

Regarding the "traditional" city of Kankan, there is a generational conflictwidespread in African societies (Whyte et al., 2008): while the youth generally creatively adapts various ways of living and dress styles that stem from different places, many elderly people tend to consider them as foreign practices that contradict local norms of the ville traditionnelle. Due to this tension between what urban dwellers consider as the local "tradition" and global ways of doing, secondary cities should be seen as intermediaries, as "nodal points" between rural areas and cosmopolitan metropolises (Ammann \& Sanogo, 2017: 6).

\section{Bouaké, the ECOWAS City}

Bouaké's urban history is linked to the Akan people and the popular narration of the Queen Abla Pokou's story (Weiskel, 1976; Atta, 1978). In the academic literature, Bouaké is often presented as a ville relais, a town linking places with each other (Diabaté, 2016): migrants would go to Bouaké for a while, but then they continued their journey either to Abidjan or to rural areas with work opportunities. In these migratory patterns, Bouaké emerged as a secondary city in the sense of being the second best option: Bouaké was seldom a final destination, migrants tended to leave for what they considered a better place.

Bouaké's dwellers refer to the city, among others, as the "best city climate-wise," because many residents compare it to humid Abidjan and hot Korhogo. Thus, in relational terms, it disposes over the best climate. Many also describe it as the "major economic center" and the "ECOWAS city." ECOWAS refers to the Economic Community of West African States, a regional economic union of fifteen West African countries. The emic term "ECOWAS city" expresses that in the perception of many dwellers, Bouaké has a strong cosmopolitan character due to its population heterogeneity. This cultural, linguistic, religious, social, and economic diversity, key to the notion of "ECOWAS city," results from the history of migration and population moves which characterizes the city along with Côte d'Ivoire in general.

Aside from forced and voluntary migration waves, mostly from what is today Burkina Faso towards present-day Côte d'Ivoire, differences in prosperity among the West African countries played an important role in the various migration waves (Akindès, 2004). The Baoulé people-who are considered in the literature (Atta, 1978), and by most Bouaké dwellers, as the "first settlers" in central Côte d'Ivoirechose to leave the city of Bouaké when they were defeated by the French military in 1898. When the French colonizers needed workers, they installed policies to attract other people to settle in Bouaké. Eventually, many Manding people from Marabadiassa, a town further north from Bouaké, settled in the city (Atta, 1978; Dubresson, 1989). Due to these and other migratory patterns, Bouaké gradually became an important trading hub and home to a heterogeneous population, much in contrast to Kankan, turning it into "ECOWAS city." 
Identity issues and urban diversity were however sensitive conversation topics during fieldwork in Bouaké, because they had the potential to stir up traumatic memories. Some of these memories dated back generations. The notion of "ECOWAS city" was then seldom brought up by urban dwellers in a proud sense of "we are diverse because we welcome everybody," unlike the Nabaya mobilized by Kankan dwellers. It was rather to express a diversity stemming from various factors such as the central location of the city (carrefour), coupled with the forced and voluntary population migrations that happened in the former centuries.

Even though both Kankan and Bouake share the characteristic of being important trading centers, they differ greatly in terms of population composition: Bouaké is a melting pot shaped by waves of migration, and residents see it as the ECOWAS city. Currently, Bouaké is characterized by strong tensions between insiders and outsiders, making the question of belonging a key theme in urban politics. Kankan, in contrast, has a rather homogeneous population in terms of religion, economy, and ethnicity. While the notion of Nabaya nevertheless stresses the city's openness, the perception of Kankan as a ville traditionnelle emphasizes its residents' attachment to "traditional" values: Newcomers are welcomed, yet only as long as they adapt to local practices.

Hilgers (2009) has identified autochthony as central to secondary cities. For him, autchochtony represents a fluid, volatile concept that is oftentimes mobilized by urban dwellers to legitimate politics of inclusion and exclusion, whether on the "first settler" logic or on the "significant economic capital" one (Hilger, 2011: 153). Our empirical data reveal that despite the strong links between historical trajectories and urban dwellers' identities, in a city like Bouaké, autochthony was carefully and seldomly used by dwellers to explain their feeling of belonging towards Bouaké. We therefore call for the importance to contextualize the nuanced relationship that dwellers have with their (secondary) city.

\section{Power (Dis)connections: Rebellious Cities}

\section{Bouaké, the Circumstantial Northern City}

Like all urban settlements, secondary cities are the outcome of their respective histories as well as of politics around identity (Hilgers, 2009). A key political rhetoric in Côte d'Ivoire in the 1990s and early 2000s was Ivority, an idea instrumentalized in politics of inclusion and exclusion, based on narratives of "them" against "us": "Them" being all those considered "foreigners", and "us" being the "real" Ivorians who could prove that their families originated from present-day Côte d'Ivoire (Akindès, 2004). The hazardous handling at the political level of this multitude of backgrounds partly led to the military-political crisis that rocked the country in the early 2000s. Due to its diverse character as ECOWAS-city, many of Bouaké's inhabitants strongly rejected the "Ivority" notion proclaimed by political elites in the power center of Abidjan. A considerable part of the city's inhabitants even took the side of the rebellion, and in 2002, the rebellion's headquarters was installed in Bouaké (until 2011), turning it into an oppositional city. Consequently, perceptions 
of Bouaké became associated with the Ivorian crisis (Fofana, 2011; McGovern, 2011; Yebouet, 2011). During that time, the civil and the armed wings of the rebellion settled in the city because of Bouaké's strategic geographical location and the population's support.

The Ivorian military-political crisis divided the country in two for about a decade. Bouaké has long been identified as belonging to the central area of the country. However, during the rebellion decade, Bouaké's inhabitants were suddenly forced to choose between a "northerner" or a "southerner" identity: A shop owner explained it like this:

Since the early 2000s, the Ivorian geography has changed a lot you know! At school, I learned that Bouaké was located in the center of Côte d'Ivoire, but in 2002, I relearned that Bouaké was located in northern Côte d'Ivoire, and that I was from then on, a northerner. I'm telling you, things have changed, even the four cardinal points! (02.12.2015, informal conversation)

The research participants we spoke to experienced this situational shift from a central geographical identity to a northerner political identity as the manifestation of how external powers could influence both the course of their lives and the relationships between their city and other Ivorian cities. Changing power hierarchies and power struggles within Bouaké, as well as between their city and other Ivorian cities, hence, influences the contextual perception of Bouaké as a secondary city.

During a lunch break with Mr. Kouamé, one of Bouaké's Town Hall officers, explained how these power hierarchies were strongly embedded in the Ivorian political history, hence the relevance of contextuality and relativity when conceptualizing secondary cities. We were in a restaurant that offered an unobstructed view on a building positioned right in the middle of the Town Hall compound, which had remained unfinished for over 50 years. Various rumors, mostly related to evil spirits that inhabit the building and forbade its completion, were circulating in Bouaké, so we asked him about his view on why the building was never finished. Mr. Kouamé explained:

Do you know the song that says that Man [a secondary city in the West of Côte d'Ivoire] will never be beautiful? The answer to your question is in this song! You see how Bouaké is? Everything that should have been in Bouaké was diverted to Yamoussoukro (01.12.2016, informal conversation).

Mr. Kouamé was referring to a song from the early 2000s by the famous Ivorian Zouglou singers Yode and Siro ${ }^{7}$. This specific song refers to the idea that a city in Côte d'Ivoire can only grow if its dwellers belong to the Ivoirian president's cultural group. The song argues that an Ivoirian city will forever remain "underdeveloped," unless one of its inhabitants becomes president and makes it his priority to "beautify" his hometown. Yamoussoukro, to which Mr. Kouamé referred, is the political capital of Côte d'Ivoire. The city was the hometown of Félix Houphouët Boigny,

\footnotetext{
7 Zouglou is an Ivoirian musical genre that became popular in the 1990s and describes societal problems in a humoristic and sarcastic way. The song title: "Tu sais qui je suis?," by Yode and Siro on the album "Victoire," was released in 2000.
} 
the country's first president. By referring to this song, Mr. Kouamé explained that the building that drew our attention was never completed because development resources went into Yamoussoukro instead of Bouaké. Even though two out of the five successive Ivoirian presidents were from the Baoule cultural group, none of them ever originated from Bouaké, which is why, according to Mr. Kouamé, the city never had the chance to "develop".

Political connections to places, parties, and people in power are key factors for a (secondary) city or town to thrive. Many of our research participants in Bouaké believe that the ability of a city to "develop" depends on political will and influence, rather than on an urban planning agenda. Unlike in a capital city or a metropolis, the power to "develop" (or not) does not lay within the secondary city itself, but needs to be attracted to the city, be it through a president or other powerful people with clientelist ties to the city. How the tension between connection and disconnection from the centers of power changes over time, hence, is a key theme for the study of secondary cities.

\section{Kankan, the Oppositional City}

National politics and the questions of belonging and power also shape the notion of Kankan as an oppositional city. At the beginning of Sékou Touré's reign (1958-1984), the majority of Kankan's inhabitants supported the president, not least because he was a Manding, like the majority of Kankan's population. Yet, because Kankan was a trading town, it suffered from the Touré government's socialist attempts to control the economy, especially trade, and Kankan's population started opposing Touré's policies. In 1975, the tensions between the Guinean government and Kankan's population increased (O'Toole \& Baker, 2005), and the city became considered as an oppositional city. This view negatively affected its economy and its infrastructure, as the Touré government indeed stopped investing in Kankan. The railway that connected the secondary city to the capital deteriorated. The construction of the international airport and of a dam that should provide electricity came to a halt because Kankan was regarded as a "bastion[...] of the counter-Revolution" (Kaba, 1977: 41). For the people we talked to, similar to those in Bouaké, it seemed obvious that the disconnection from the central power, related to its conflicting relationship with the country's president, negatively impacted this city's infrastructure.

The relationship between Kankan and Lansana Conté, Guinea's head of state between 1984 and 2008, was not much better. Kankan's Manding population was suspicious of this president, not least because he built his power mainly through members of his own socio-cultural group (Camara, 2014). In October 1991, government troops fired on demonstrators in Kankan, an incident that further fueled the tensions between the president and the secondary city (Camara et al., 2014). At the beginning of the 1990s, Kankan's oppositional role became even more pronounced as the majority of its inhabitants supported Alpha Condé, a Manding dissident. During the 1993 presidential elections, the government annulled the ballots in Kankan where Condé was supposed to win. Only in 2005 the national government accepted election results putting Alpha Condé's opposition party in power in Kankan and 
two other secondary cities in the Upper Guinea Region (International Crisis Group, 2003, 2006). Kankan, now even governed by the opposition party, therefore consolidated its image as an oppositional city.

The cases of Bouaké and Kankan both highlight that secondary city's historical political affiliations have lasting effects on its standing on the national level-especially if they are considered as rebels (Hilgers, 2009)_affecting also the "development" of its infrastructure. For the constitution of secondary cities, this politics of belonging is of huge importance, not least because it goes along with connection-or rather disconnection-from power and its related resources. The situation of Bouaké, located in the center of Côte d'Ivoire, changed radically as it became the headquarter of the rebellion in 2002, temporarily transforming it into a northern secondary city. Kankan's population suffered for a long time from the central government's neglect, because it was considered an oppositional city. Yet, its contextual standing also altered quickly: in 2010, Kankan's favorite, Alpha Condé, one of "theirs", became Guinea's head of state. Through that ascension, the oppositional city suddenly became drawn into the networks of influence and power, a change that raised many hopes for an economic and infrastructural boom among its inhabitants, which in reality were only partly met.

\section{Infrastructure “Development": Aspirational Cities}

\section{Kankan, the Second City After Conakry}

Secondary cities like Bouaké and Kankan tend to be cities in the making, with a population aspiring their city to become better "developed" in terms of urban infrastructure. Sory, the president of an NGO in Kankan, founded by a group of young, unemployed graduates, dreamt for Kankan to compete not only with Conakry, but also with cities such as Paris or New York. Thanks to his active engagement in Condé's ruling party, Sory personally met the president's wife. He hoped that this contact would enable his NGO to receive the funds to enlarge its activities to the whole Guinean territory. Personally, Sory expected that the contact with the First Lady might offer him possibilities. Indeed, in April 2016, Sory, as the president of his NGO, was given the opportunity to travel to China for a training in project management.

In Kankan, there is the widespread perception that its level of infrastructural construction is much lower than it should be for the city's status as the country's second most populated city. Due to this lack of basic infrastructure, its urban character is sometimes put into question. For the authors of the Guinean Dictionary, Kankan was in the early 2000s "more a large cluster of Maninka villages around an administrative and commercial core than a truly urban area" (O'Toole \& Baker, 2005: 121). This link between the city's infrastructure and the dwellers' aspirations to be second, right after Conakry, is often highlighted by the local population and the administration. On the occasion of the "Forum for the Development of Kankan's Prefecture" Mr. Khalil, a civil servant, said: "Kankan has a huge economic potential and important natural and human resources for a prosperous economy. But the city is 
still totally underdeveloped. Thus, I welcome everyone to invest in Kankan so that it might regain its real value as Guinea's second city, a place it had since colonial times" (12.11.2011, recordings). According to him, due to being the second city in terms of population size, the aspiring city of Kankan deserves the appropriate urban infrastructure.

Since Alpha Condé came to power, many of Kankan's inhabitants started to refer to their hometown as a city of change (Ammann 2020). Between August 2011 and March 2013, some infrastructural changes in Kankan were indeed eye-catching: for example, public electricity became available at least at night. Major roads were tarred, there was also more traffic, and some foreigners working in the mining and NGO sectors came back to the city. Finally, the government invested in Kankan's public infrastructure; it constructed new administrative buildings, a handicraft, and a youth center, as well as a bus station.

Similar to Sory in the vignette above, Mr. Kaba, the owner of one of the biggest local enterprises, evaluated Kankan's change not in comparison with other regional (secondary) cities, but in contrast to countries in the Global North: "We can be proud of Kankan in 2014. In 2009, it was a hole; it was difficult to circulate by car or by motorcycle. Now we can establish a slight progress. We are not on the same level as the United States, we do not have the same infrastructures as France, but we progress slowly according to our means?" (Sonomou, 2014, authors' translation). Urban dwellers' normative perceptions of their secondary city tend to be influenced by how they evaluate the sophistication of its infrastructure-or lack thereof-in comparison with other small and big cities they are familiar with. Dwellers' personal biographies often become mixed with their professional and political aspirations for the future "development" of their city.

\section{Bouaké, Korhogo's Senior Brother}

Kofi is a moto taxi driver in his thirties. He lived in Ghana during the military-political crisis decade and had recently visited friends in Korhogo when we met him in 2014. Kofi claimed that very few cities in West Africa could compare to Bouaké: he believed that its geographical location gave Bouaké an advantage for trade within Côte d'Ivoire and within the West African region. Yet Kofi blamed the rebellion period for the deterioration of his beloved city's infrastructure. He considered it unfair that Korhogo had better infrastructure than Bouaké, even though, in his eyes, Bouaké had much more economic potential. According to him, Korhogo surpassed Bouaké's infrastructure level thanks to the influence of its former rebellion chief. Kofi asserted that Bouaké, in contrast to Korhogo, did not benefit from such rebellion leadership. Comparing Bouaké and Korhogo to brothers, Bouaké being the senior one, Kofi explained the relationship using an allegory:

In a family, the senior brother is the leader and sets the example for the junior brother. Even if afterwards the junior brother succeeds in life, the senior brother remains the one who takes care of the family businesses, for example for family functions (04.11.2014, informal conversation). 
That Korhogo surpassed Bouaké in terms of infrastructure runs against Kofi's rule of seniority, which is why Bouaké should return to be Korhogo's "senior brother," by refurbishing all its infrastructures to regain its former glory. He advocated for factory reconstruction and believed that other companies should be reopened to serve as employment providers. Kofi experienced being out-performed by Korhogo as shameful and a failure.

Public infrastructures in urban areas oftentimes represent backbones around which issues of identities and various power relations among urban citizens are constantly constructed and reconfigured (Fredericks, 2018: 150). As for Kofi, one of his best friends managed to climb up the social ladder and build a house in Korhogo, thanks to his active involvement in the rebellion. Kofi's friend was not younger than him in terms of biological age, but Kofi used to "help him out" financially. After the rebellion, these roles became reversed, and Kofi aspired to reverse the power balance in their friendship and claim back his former social elder status. Hence, in secondary cities like Kankan and Bouaké, a strong link can be observed between dwellers' life trajectories and their perceptions of their living environment.

\section{Concluding Reflections}

Secondary cities as ordinary cities "that are still too often 'off the map' are telling stories that should change the narrative" (Myers, 2018: 248). They are not as spectacular, nor can they as easily be branded like metropolises, yet this fact is no justification for their neglect in the scholarly literature. Secondary cities play an important role in rural-urban migration and thus constitute an urban middle ground between metropolises on the one hand and the rural hinterland on the other. They continue to grow worldwide in terms of numbers and population size. Therefore, we claim that more research is needed on secondary cities and how life in them unfolds, not least because this analysis pluralizes our understandings of what urbanity is.

We believe that an all-embracing definition of secondary cities is not fruitful, because they may share some characteristics but not others. Understanding secondary cities in relational and contextual terms, as we did in this article, should produce research that closely analyzes the specificities of a particular secondary city, by describing its characteristics in detail, while also bringing to the fore recurring themes peculiar to many secondary cities. The examples of Bouaké and Kankan demonstrate that it would be wrong to juxtapose the heterogeneity often associated with metropolises to an apparent homogeneity of secondary cities. While both are secondary cities, their social, cultural, economic, and religious composition lead to very different local conceptions of what characterizes their urbanity.

Still, Bouaké and Kankan share characteristics that we believe to be typical for secondary cities. Many secondary cities as well as their inhabitants thrive to occupy a more important role within the national or regional context. The history of their relationship to the center of power highly impacts their current infrastructure. Yet, secondary cities can also be very distinct in many ways, not least related to their specific historical, political, economic, and social trajectories. Hence, it is important 
to acknowledge the diversity of secondary cities in Africa and beyond. As a fruitful lens to explore such shared and diverse characteristics, we propose approaching secondary cities empirically through emic perspectives, thus highlighting the diversity of perceptions held by their respective inhabitants. This entails paying attention to urban dwellers' own experiences of cities, and how they perceive them in comparison with elsewhere.

When comparing ethnographically, the secondary cities of Kankan and Bouaké, three recurring themes have emerged. First, urban dwellers create ideas about the specific form of urbanity, related to the cities' social, cultural, economic, and religious composition. While Kankan is locally seen as the Nabaya city, shaped by Muslim and Manding culture, Bouaké with its heterogeneous population from all over West Africa is called by many of its inhabitants the ECOWAS city. Second, the cities' power (dis)connections within the political hierarchies at the national scale are important. Both cities were considered rebellious during a certain time of their urban and political history. While this may not be a typical characteristic of secondary cities, it hints at the importance of power struggles within which secondary cities are situated at the national level.

We believe that one common feature of secondary cities is power games: secondary cities struggle to attract national and international investors and aim to receive a larger part of the national budget to develop their infrastructure. As our data illustrates, such projects seem to be most promising if a city is on good terms with the party in power, even more so if important personalities stem from that very city. Therefore, the consequences of personalized power politics have a marked impact on secondary cities. Nation-wide divisions around ethnicity, regional identities, religious affiliations, or other categories can shape power struggles among secondary cities over limited resources. Lastly, the cities' infrastructure is always seen in comparison with elsewhere. Both Kankan and Bouaké are aspirational cities in progress, because their urban dwellers have aspirations for how their city and their own lives should change-in ways that can intermingle personal histories and the past or present situation of their cities.

Acknowledgements We would like to thank Rita Kesselring and Silke Oldenburg for comments on an earlier version of this manuscript and anonymous reviewers for their thoughtful and helpful feedbacks. We are also thankful for the funding by the Swiss National Science Foundation.

Code Availability Not applicable

Author Contribution CA and AS equally contributed to this paper. They collected the data and jointly wrote the article with $\mathrm{BH}$.

Funding This work was supported by the Swiss National Science Foundation (grant numbers 149355, 124528, and 164550)

Data Availability Due to anonymity reasons, the data for this article is not made available.

\section{Declarations}

Conflict of Interest The authors declare no competing interests. 
Open Access This article is licensed under a Creative Commons Attribution 4.0 International License, which permits use, sharing, adaptation, distribution and reproduction in any medium or format, as long as you give appropriate credit to the original author(s) and the source, provide a link to the Creative Commons licence, and indicate if changes were made. The images or other third party material in this article are included in the article's Creative Commons licence, unless indicated otherwise in a credit line to the material. If material is not included in the article's Creative Commons licence and your intended use is not permitted by statutory regulation or exceeds the permitted use, you will need to obtain permission directly from the copyright holder. To view a copy of this licence, visit http://creativecommons.org/licen ses/by/4.0/.

\section{References}

Akindès, F. (2004). Les Racines de la Crise Militaro-Politique en Côte d'Ivoire. In Série de Monographies. CODESRIA.

Atta, K. (1978) Dynamique de l'Occupation de l'Espace Urbain et Péri-Urbain de Bouaké (Côte d'Ivoire). PhD Thesis, Ecole des Hautes Etudes en Sciences Sociales, France.

Ammann, C. (2020). Women, Agency, and the State in Guinea. Silent Politics. Routledge

Ammann, C. \& Sanogo, A. (2017). Secondary Cities - The Urban Middle Ground. An Introduction. Basel Paper on Political Transformations (11-12), 5-9.

Baker, J. (Ed.). (1990). Small town Africa. Studies in rural-urban interaction (23rd ed.). Nordic Africa Institute.

Baker, J. (Ed.). (1997). Rural-urban dynamics in Francophone Africa. Nordic Africa Institute.

Bell, D., \& Jayne, M. (2006). Small cities: urban experience beyond the metropolis. Routledge.

Bell, D., \& Jayne, M. (2009). Small cities? Towards a research agenda. International Journal of Urban and Regional Research, 33(3), 683-699.

Bertrand, M. (1997). Les villes secondaires d'Afrique noire. CEAN.

Bertrand, M., \& Dubresson, A. (Eds.). (1997). Petites et moyennes villes d'Afrique noire. Karthala.

Camara, M. S. (2014). Political history of Guinea since World War Two. Peter Lang.

Camara, M. S., O’Toole, T., \& Baker, J. E. (2014). Historical dictionary of Guinea (5th ed.). The Scarecrow Press.

Côté-Roy, L., \& Moser, S. (2019). 'Does Africa not deserve shiny new cities?' The power of seductive rhetoric around new cities in Africa. Urban Studies, 56(12), 2391-2407.

De Boeck F., Cassiman A. \& Van Wolputte S. (2009). Recentering the city: an anthropology of secondary cities in Africa. African Perspectives, 33-41. Available at: https://lirias.kuleuven.be/1796121? limo $=0$ (accessed 26 October 2021).

Diabaté, I. (2016). Bouaké, de Nombreux Peuples Une Seule Cité (1858-1999). SNPECI.

Dubresson, A. (1989). Villes et Industries en Côte d'Ivoire: Pour une Géographie de l'Accumulation Urbaine. Karthala.

Edensor, T., \& Jayne, M. (2012). Introduction: urban theory beyond the West. In T. Edensor \& M. Jayne (Eds.), Urban theory beyond the West: a world of cities (pp. 1-27). Routledge.

Fofana, M. (2011). Des Forces Nouvelles aux Forces Républicaines de Côte d'Ivoire. Comment une Rébellion devient Républicaine. Politique Africaine, 122, 161-178.

Förster, T. (2013). On urbanity. Creativity and emancipation in African urban life. In B. Obrist van Eeuwijk, V. Arlt, \& E. Macamo (Eds.), Living the City in Africa (pp. 235-252). Lit Verlag.

Fredericks, R. (2018). Garbage citizenship. In Vital infrastructures of labor in Dakar, Senegal. Duke University Press.

Geschiere, P., Meyer, B. \& Pels, P. (2008). Introduction. In Readings in Modernity in Africa. In: P. Geschiere, B. Meyer \& P. Pels (Eds.), Readings in Modernity in Africa (pp. 1-7). James Currey.

Goerg, O. (1986). Commerce et Colonisation en Guinée (1850-1913). L'Harmattan.

Gough, K. V. (2012). Reflections on conducting urban comparison. Urban Geography, 33(6), 866-878.

Heer, B. (2019). Cities of Entanglements. Social Life in Johannesburg and Maputo Through Ethnographic Comparison. transcript Verlag.

Hilger, M. (2011). L'autochtonie comme capital. Appartenance et citoyenneté dans l'Afrique urbaine. Social Anthropology, 19(2), 143-158. 
Hilgers, M. (2009). Une ethnographie à l'échelle de la ville. Urbanité, histoire et reconnaissance à Koudougou, Burkina Faso. Karthala.

Hilgers, M. (2012). Contribution à une anthropologie des villes secondaires. Cahiers d'études africaines, 205(1), 29-55.

International Crisis Group (2003) Guinée. Incertitude autour d'une fin de régne. Rapport d'Afrique $\mathrm{N}^{\circ}$ 74. International Crisis Group.

International Crisis Group. (2006). La Guinée en transition. Briefing Afrique $\mathrm{N}^{\circ} 37$. International Crisis Group.

John, L. (2012). Secondary cities in South Africa: the start of a conversation. South African Cities Network.

Kaba, L. (1977). Guinean politics. A critical historical overview. The Journal of Modern African Studies, 15(1), 25-45.

Koechlin, L., \& Förster, T. (2018). Secondary cities and the formation of political space in West and East Africa. In G. B. Prato \& I. Pardo (Eds.), The Palgrave Handbook of Urban Ethnography Basingstoke (pp. 351-368). Palgrave MacMillan.

Krause, M. (2013). The ruralization of the world. Public Culture, 25(2), 233-248.

Malaquais, D. and Diallo, K. (2013) Igniting Sparck. In: E. Pieterse \& AM. Simone (Eds.), Rogue Urbanism. Emergent African Cities (pp.55-65). Jacana Media \& ACC.

Marais, L., \& Cloete, J. (2017). The role of secondary cities in managing urbanisation in South Africa. Development Southern Africa, 34(2), 182-195.

Marais, L., Nel, E., \& Donaldson, R. (2016). Secondary cities and development. Routledge.

McGovern, M. (2011). Making War in Côte d'Ivoire. Hurst \& Company.

Mukhopadhyay, P., Zérah, M. H., \& Denis, E. (2017). Subaltern urbanization revisited. India International Centre Quarterly, 43(3-4), 26-41.

Mukhopadhyay, P., Zérah, M. H., \& Denis, E. (2020). Subaltern urbanization: Indian insights for urban theory. International Journal of Urban and Regional Research, 44(4), 582-598.

Murray, M., \& Myers, G. (Eds.). (2007). Cities in contemporary Africa. Palgrave MacMillan.

Myers, G. (2018). The Africa problem of global urban theory: re-conceptualizing planetary urbanization. International Development Policy, 10, 231-253.

Osborn, E. L. (2011). Our new husbands are here. Households, gender, and politics in a West African state from the slave trade to colonial rule. Ohio University Press.

O’Toole, T., \& Baker, J. E. (2005). Historical dictionary of Guinea. the Scarecrow Press.

République de Guinée. (2014). Rapport de la République de Guinée sur l'Evaluation de la Mise en Oeuvre du Programme d'Action de Beinjing +20. Ministre de l'Action Sociale, de la Promotion Féminine et de l'Enfance.

Rey, P. (2016). Une gouvernance locale à l'épreuve du temps. Politiques nationales, pouvoirs locaux et stratégies des miniers en Guinée. Stichproben. Vienna Journal of African Studies, 16(30), 87-110.

Roberts, B. H. (2014). Managing systems of secondary cities. Available at: http://www.citiesalliance.org/ sites/citiesalliance.org/files/1d\%20\%28i\%29\%20-\%20Managing\%20Systems $\% 20$ of $\% 20$ Secondary\% 20Cities\%20Book_low_res.pdf (accessed 12 Januray 2018).

Roberts, B., \& Hohmann, R. P. (2014). The system of secondary cities: the neglected drivers of urbanising economies. In CIVIS (ed), Sharing knowledge and learning from cities 7 (pp. 1-12). Cities Alliance.

Robinson, J. (2013). "Arriving at" urban policies/the urban: traces of elsewhere in making city futures. In O. Söderström, S. Randeria, D. Ruedin, G. D’Amato, \& F. Panese (Eds.), Critical Mobilities (pp. 1-28). Routledge.

Sanogo, A. (2019). 'That the way it is.' Urban land governance in Bouaké, Côte d'Ivoire, unpublished $\mathrm{PhD}$ thesis. University of Basel

Sorensen, A. \& Labbé, D.( 2020). Megacities, megacity-regions, and the endgame of urbanization. D. Labbé \& A. Sorensen (eds.). Handbook of Megacities and Megacity Regions (pp. 1-19). Edward Elgar Publishing.

Schmidt-Lauber, B. (2010). Urbanes Leben in der Mittelstadt. Kulturwissenschaftliche Annäherung an ein interdisziplinäres Forschungsfeld. In B. Schmidt-Lauber (Ed.), Mittelstadt: Urbanes Leben jenseits der Metropole (pp. 11-36). Campus Verlag.

Sonomou, E. (2014) Manif des jeunes à Kankan: 'GUITER S.A a du matériel suffisant pour exécuter les contrats, mais ...'. Guinée News. Available at http://guineenews.org/manif-des-jeunes-a-kankanguiter-s-a-a-du-materiel-suffisant-pour-executer-les-contrats-mais-elle-doit-recevoir-de-largent-dugouvernement/ (accessed 26 June 2015). 
Umbach, M. (2005). A tale of second cities: autonomy, culture, and the law in Hamburg and Barcelona in the late nineteenth century. The American Historical Review, 110(3), 659-692.

UN Habitat. (2016). Urbanization and development. Emerging futures. World Cities Report.

Van der Merwe, I. J. (1992). In search of an urbanization policy for South Africa: towards a secondary city strategy. Geography Research Forum, 12, 102-127.

Werthmann, K. (Ed.). (2004). Diébougou, une petite ville du Burkina Faso. Johannes Gutenberg-Universität.

Weiskel, T. C. (1976). L'Histoire Socio-Economique des Peuples Baule. Cahiers d'Etudes Africaines (16): 357-395.

Whyte, S. R., Alber, E., \& Van der Geest, S. (2008). Generational connections and conflicts in Africa: an introduction. In E. Alber, S. Van der Geest, \& S. R. Whyte (Eds.), Generations in Africa: Connections and conflicts (pp. 1-23). LIT Verlag.

Yebouet, H. (2011). La Côte d'Ivoire au Lendemain de la Crise Post-Electorale: Entre Sortie de Crise Politique et Défis Sécuritaires. Sécurité et Stratégie, 3(7), 22-32.

Publisher's Note Springer Nature remains neutral with regard to jurisdictional claims in published maps and institutional affiliations. 